\title{
COMMENTED LIST OF RARE AND PROTECTED VASCULAR PLANTS OF INLAND WATER BODIES OF ESTONIA
}

\author{
Helle Mäemets \\ Centre for Limnology at Estonian University of Life Sciences, Estonia \\ e-mail: helle.maemets@emu.ee
}

Received: 30.09 .2016

\begin{abstract}
This presented overview of rare and protected hydrophytes, emergent plants and hygrophytes of inland water bodies of Estonia includes 60 species. In the commented list are indicated their position in the state protection categories I-III (last version in 2014), and under the Red List of Estonia (last version in 2008); marked are Natura 2000 species of the European Union. Most typical habitats for these rare species are: I. soft-water oligotrophic and semidystrophic lakes; II. mesotrophic lakes with Najas (Caulinia) flexilis and Potamogeton rutilus; III. alkaline fens and wet meadows; IV. brackish or freshwater coastal lagoons; V. undamaged river stretches; VI. open shallow littoral of the largest lakes of Peipsi (Pskovsko-Chudskoe) and of Võrtsjärv. Main threats of these habitats are briefly concerned, as well as the problem of conservation value of hybrids, based on the example of Sparganium species.
\end{abstract}

Key words: hybrids, main habitats, protection categories, Red List, threats.

\section{Introduction}

The presented overview of rare aquatic and moisture-demanding plants is restricted to the species of inland water bodies as the author has a 20-year experience in this field. Numerous rare plants of the seashore need a special approach; here are included some species of coastal lagoons. To draw a line between the shore species i.e. to include them or not, is difficult. Therefore, the selection of shore species is more or less subjective, and several representatives of Orchidaceae (all species are under protection in Estonia) were left, despite their occasional occurrence along water. Some species that are considered to be very rare by terrestrial botanists are growing in the vicinity of the lakes, and are commented here as not critically endangered. The location of Estonia on the border of West and East, on the border of marine and continental climate, and the transition between limestone and sandstone bedrock - all these factors cause a large number of species that are on the distribution border here. Therefore, altogether 538 species are on the border of their distribution area (among 1538 native species according to Kukk, 1999), and many of these species are rare. In Estonia, rare plants are protected:

1) under the state protection categories I-III established in 2014; addresses https://www.riigiteataja.ee/akt/118062014020; https://www.riigiteataja. ee/akt/104072014022;

2) under the Estonian Red List; last version since 2008 (http://www.zbi.ee/punane/);

3 ) under the Natura species of European Union, established in 2000 (www.natura2000.envir.ee/files/ doc/eestiliigid.pdf).
Most of the protected species display a declining distribution because of a decrease in suitable habitats. Not all rare plants belong to protection categories, mainly for two reasons: they have been found lately (e.g. Potamogeton acutifolius Link) and/or their distribution is not sufficiently studied (e.g. Sparganium glomeratum Laest ex Beurl.). Some rare species are invaders or grow in disturbed habitats. In the case of Lemna gibba L., considered as vulnerable, suitable nutrient-rich habitats do not spread widely until now. In the opinion of the author, most of nutrient-demanding aquatic taxa do not need any protection status, considering that anthropogenic eutrophication of water bodies is an unwanted process.

\section{Material and Methods}

A. Mäemets (1988) published characterisations of habitats for several Potamogeton species in the Flora of Estonia IX in 1984, and an overview of the status of rare aquatic plants of Estonia in 1988. In 2011, H. Mäemets compiled a report on the status and protection plans for seven rare hydrophyte species (genera Lobelia, Isoëtes, Sparganium, Myriophyllum, Najas) for the Estonian Board of Environment; and some graduation papers have been compiled on this topic. Also, the Atlas of the Estonian Flora (2005) and the database of lake macrophytes at the Estonian University of Life Sciences served as the basis for the article. Although the previous distribution atlas was published in 2005, data for many species had been collected far earlier - in the 1970s and 1980s. This shortage of recent data does not count for hydrophytes, as most of the lakes with earlier finds of rare species have been revisited since 
2000. Undoubtedly, for several species, the protection categories require revision and for some species, the status in the Red List and the protection category differ too much. We hope that the best time for a change will come when field work (in 20152016) and data analyse for the new Atlas of the Estonian Flora are finished.

\section{Results and Discussion}

COMMENTS ON THE SPECIES LIST. The species in Table 1 are arranged alphabetically: at first in every group of protection categories. Then follow the species having protection status only according to the Red List, and Natura 2000 species are marked too. We can see some inconsistency between the protection categories and Red List, needing correction. Below are characterised the main typical habitats of rare species and threats to their continuing existence. Sufficient information about the typical growth conditions of all species is not available, but in Table 1 have been added some comments about the distribution in Estonia.

I. Soft-water $\left(\mathrm{HCO}_{3}^{-}\right.$mostly $\left.<50 \mathrm{mg} \mathrm{l}^{-1}\right)$ lakes: oligotrophic and semidystrophic (yellowish water), located on sands of the melting waters of the Late Glacial or in old coastal dunes. Besides Lobelia dortmanna L., Isoëtes spp., Sparganium angustifolium Michx. and S. gramineum Georgi, also submerged mosses may occur up to a depth of 8-10 $\mathrm{m}$. The main threats are: a) drastic drop in water level; b) erosion of shores (including logging works); c) transport of gravel and sand from quarries to improve the beach; d) pollution by detergents and other chemicals at camping sites; e) trampling in the Lobelia belt. Until the first decades of the $20^{\text {th }}$ century also flax retting caused deterioration many of these lakes, as a result of which they lack character species today. With an increasing trophy level common species invade these lakes, occupying the zone of isoetids; the species of Sparganium and Nuphar undergo introgressive hybridisation. Several lakes of this group are bordered by peat-bogs, and the increasing inflow of humic compounds and expanding peat sediments reduce suitable conditions for the character species. Furthermore, holidaymakers exploit the diminishing sandy stretches and destroy the last stands of rare plants.

II. Lakes with Najas flexilis Rostk. \& W.L.E. Schmidt and Potamogeton rutilus Wolfg. have moderate $\left(\mathrm{HCO}_{3}^{-} 80-220 \mathrm{mg} \mathrm{l}^{-1}\right)$ or high alkalinity $\left(\mathrm{HCO}_{3}\right.$ $>220 \mathrm{mg} \mathrm{l}^{-1}$ ); they are mesotrophic and shallow. The reasons for the drastic decline of Najas flexilis in Europe are unclear. According to palaeobotanical data, an increase in Picea abies and acidification occurred at the time of its disappearance in Poland (Gałka et al., 2012). At the sites in Estonia, the masses of large robust Chara spp. seem to suppress this small-sized plant. The inflow of nutrients (especially nitrogen?), decreasing water transparency, overgrowing by helophytes and nymphaeids and accumulation of mud all these phenomena could explain this decline. Interestingly, in all Najas-lakes, Potamogeton rutilus has been found or recently is growing there. According to data from Poland (Gałka et al., 2012), an accompanying species may be also Potamogeton pusillus $\mathrm{L}$.

III. Alkaline fens and wet meadows (see also Paal, 2007) provide the habitat for many declining species, however, they have undergone significant depletion during the last decades. Dactylorhiza spp., Epipactis palustris (L.) Crantz, Primula farinosa L., Pinguicula vulgaris L., Saxifraga hirculus L. and several species of the small-sized Carex inhabit these areas. Wet meadows have disappeared in recent decades, overgrown by Salix spp. and other bushes and trees. Alkaline fens near the water's edge are overgrown by Phragmites australis (Cav.) Trin. ex Steud. and other tall helophytes; on some lake shores the expansion of eutrophic quagmire takes place.

IV. On the shores of old coastal lagoons (brackish or freshwater) are growing mighty stands of Cladium mariscus (L.) Pohl; in the western part of Saaremaa Island it is accompanied by Schoenus nigricans L., while Hydrocotyle vulgaris L. occurs in the western part of the islands of Saaremaa and Hiiumaa. Human impact on the status of these water bodies may be of lesser importance in comparison with the neotectonic rise of the Earth's crust (the largest in northwestern Estonia), which causes receding of water and overgrowing by Phragmites and Typha angustifolia L. The typical representatives of the shore mires Cladium mariscus and Schoenus ferrugineus L. belong to the species of responsibility, because in Estonia their status is better than in neighbouring countries (Paal \& Leibak, 2013). Najas marina ssp. intermedia (Wolfg. ex Gorski) Casper is frequent in some lagoons and bays of West Estonia, Saaremaa and Hiiumaa. Also Potamogeton filiformis Pers., P. rutilus and P. pusillus may occur in these water bodies.

$\mathrm{V}$. In the rivers two protected species are growing: Berula erecta (Huds.) Coville and Stuckenia $\times$ fennica (Hagstr.) Holub $[S$. filiformis $\times$ S. vaginata $]$ (Potamogeton $\times$ meinshausenii Juz.). Berula can be found in different catchment basins, but mainly in western and northern Estonia, in small rivers on the alkaline bedrock, also at high trophy level. The stands of Berula are viable but spread mainly vegetatively (Trei, 2001). $S . \times$ fennica is found in fast-flowing stretches of rivers of eastern Estonia; always only vegetative plants are present. Threats to their continuing existence may arise from damming up by beavers, or from pollution or major modification of the river by man. 
Table. The list of endangered and protected vascular plants of water bodies in Estonia

\begin{tabular}{|c|c|c|c|c|}
\hline Species & $\begin{array}{c}\text { Protection } \\
\text { category }\end{array}$ & $\begin{array}{l}\text { Status in } \\
\text { Red List }\end{array}$ & $\begin{array}{l}\text { Natura } \\
2000\end{array}$ & Comments \\
\hline Isoëtes echinospora Durieu & I & $\begin{array}{l}\text { Regionally } \\
\text { Extinct }\end{array}$ & & Last confident find in 2001 \\
\hline Littorella uniflora L. & I & Vulnerable & & $\begin{array}{l}\text { In water bodies of the western coast of Saaremaa } \\
\text { Island }\end{array}$ \\
\hline $\begin{array}{l}\text { Najas flexilis Rostk. \& W.L.E. } \\
\text { Schmidt (Caulinia flexilis Willd.) }\end{array}$ & I & $\begin{array}{l}\text { Regionally } \\
\text { Extinct }\end{array}$ & $\mathrm{X}$ & Last confident find in 2012 \\
\hline Isoëtes lacustris L. & II & Endangered & & In 2011 found in 15 soft-water lakes \\
\hline Lycopodiella inundata (L.) Holub & II & Endangered & $\mathrm{X}$ & In fens, rarely in mires bordering the lakes \\
\hline Alisma gramineum Lej. & II & Vulnerable & & Mainly in Lake Peipsi \\
\hline Berula erecta (Huds.) Coville & II & $\begin{array}{c}\text { Near } \\
\text { Threatened }\end{array}$ & & Mainly in rivers of western and northern Estonia \\
\hline Bidens radiata Thuill. & II & Vulnerable & & Mainly on the shore of L. Peipsi \\
\hline Ceratophyllum submersum L. & II & Endangered & & In last time several new finds \\
\hline Cyperus fuscus L. & II & $\begin{array}{c}\text { Near } \\
\text { Threatened }\end{array}$ & & Mainly on the shore of L. Peipsi \\
\hline Elatine hydropiper L. & II & Vulnerable & & The largest population in L. Peipsi \\
\hline Gentiana pneumonanthe L. & II & Vulnerable & & Mainly in fens of basin of L. Peipsi \\
\hline Hydrocotyle vulgaris $\mathrm{L}$. & II & Endangered & & $\begin{array}{l}\text { In the northwest part of islands of Saaremaa and } \\
\text { Hiiumaa }\end{array}$ \\
\hline Lobelia dortmanna $\mathrm{L}$. & II & Vulnerable & & $\begin{array}{l}\text { In eight soft-water lakes; needs I category due to } \\
\text { direct damage by recreation activities }\end{array}$ \\
\hline Myriophyllum alterniflorum DC & II & Vulnerable & & $\begin{array}{l}\text { In seven soft-water lakes; some large populations. } \\
\text { Transient? }\end{array}$ \\
\hline $\begin{array}{l}\text { Najas marina L. ssp. intermedia } \\
\text { (Wolfg. ex Gorski) Casper }\end{array}$ & II & Vulnerable & & Mainly in coastal water bodies of western Estonia \\
\hline $\begin{array}{l}\text { Potamogeton trichoides Cham. \& } \\
\text { Schltdl. }\end{array}$ & II & $\begin{array}{c}\text { Near } \\
\text { Threatened }\end{array}$ & & $\begin{array}{l}\text { Transient, in lately cleaned canals and ponds of L. } \\
\text { Peipsi }\end{array}$ \\
\hline Rhynchospora fusca (L.) W.T. Aiton & II & Endangered & & $\begin{array}{l}\text { Mainly in northwest Estonia, rarely on shore of } \\
\text { lakes }\end{array}$ \\
\hline Saxifraga hirculus L. & II & Endangered & $\mathrm{X}$ & In alkaline fens; rarely in mires bordering the lakes \\
\hline Schoenus nigricans L. & II & Vulnerable & & $\begin{array}{l}\text { In northwest Estonia; in fens and on shore of } \\
\text { coastal lagoons }\end{array}$ \\
\hline Scirpus radicans Schkuhr & II & $\begin{array}{c}\text { Near } \\
\text { Threatened }\end{array}$ & & In eastern Estonia, mainly on the shore of L. Peipsi \\
\hline Sparganium angustifolium Michx. & II & Endangered & & $\begin{array}{l}\text { Small populations in } 10 \text { soft-water lakes; only five } \\
\text { pure (?) populations }\end{array}$ \\
\hline Sparganium gramineum Georgi & II & Endangered & & $\begin{array}{l}\text { In soft-water lakes; only one pure population; } \\
\text { hybrids in } 10 \text { lakes }\end{array}$ \\
\hline Cladium mariscus (L.) Pohl & III & $\begin{array}{c}\text { Near } \\
\text { Threatened }\end{array}$ & & $\begin{array}{l}\text { Abundant in fens and coastal lagoons in western } \\
\text { Estonia }\end{array}$ \\
\hline Epipactis palustris (L.) Crantz & III & - & & Frequent in fens; at lakes too \\
\hline Myrica gale $\mathrm{L}$. & III & $\begin{array}{c}\text { Near } \\
\text { Threatened }\end{array}$ & & $\begin{array}{l}\text { Common in mires and lakeshores of western } \\
\text { Estonia, occurs also in northeast Estonia }\end{array}$ \\
\hline Nuphar pumila (Timm) DC. & III & Vulnerable & & $\begin{array}{l}\text { More often in southeast Estonia; hybrids with } N \text {. } \\
\text { lutea frequent }\end{array}$ \\
\hline Nymphaea alba L. & III & $\begin{array}{c}\text { Near } \\
\text { Threatened }\end{array}$ & & Mostly hybrids, few pure populations \\
\hline $\begin{array}{l}\text { Nymphaea candida C. Presl \& J. } \\
\text { Presl }\end{array}$ & III & $\begin{array}{c}\text { Near } \\
\text { Threatened }\end{array}$ & & Hybrids very frequent \\
\hline Potamogeton filiformis Pers. & III & - & & $\begin{array}{l}\text { Mainly in coastal lakes, in L. Võrtsjärv and in L. } \\
\text { Peipsi }\end{array}$ \\
\hline Potamogeton pusillus L. & III & $\begin{array}{c}\text { Near } \\
\text { Threatened }\end{array}$ & & Mainly in coastal lakes and in L. Peipsi \\
\hline Betula humilis Schrank & & Vulnerable & & $\begin{array}{l}\text { In fens, rarely at alkaline lakes. Species of } \\
\text { responsibility }\end{array}$ \\
\hline Callitriche cophocarpa Sendt. & & $\begin{array}{c}\text { Near } \\
\text { Threatened }\end{array}$ & & Distribution under-estimated \\
\hline Callitriche hermaphroditica L. & & $\begin{array}{c}\text { Near } \\
\text { Threatened }\end{array}$ & & Distribution data insufficient \\
\hline
\end{tabular}


The end of the Table

\begin{tabular}{|c|c|c|c|c|}
\hline Species & $\begin{array}{c}\text { Protection } \\
\text { category }\end{array}$ & $\begin{array}{l}\text { Status in } \\
\text { Red List }\end{array}$ & $\begin{array}{c}\text { Natura } \\
\mathbf{2 0 0 0}\end{array}$ & Comments \\
\hline Callitriche palustris L. & & $\begin{array}{c}\text { Near } \\
\text { Threatened }\end{array}$ & & Distribution data insufficient \\
\hline Callitriche stagnalis Scop. & & $\begin{array}{c}\text { Near } \\
\text { Threatened }\end{array}$ & & Distribution under-estimated \\
\hline Catabrosa aquatica (L.) P. Beauv. & & $\begin{array}{c}\text { Near } \\
\text { Threatened }\end{array}$ & & Scattered distribution \\
\hline Eleocharis mamillata $\mathrm{H}$. Lindb. & & $\begin{array}{c}\text { Near } \\
\text { Threatened }\end{array}$ & & $\begin{array}{l}\text { At the water's edge of small lakes, probably under- } \\
\text { estimated }\end{array}$ \\
\hline Galium trifidum L. & & $\begin{array}{c}\text { Critically } \\
\text { Endangered }\end{array}$ & & In last time new finds in quagmires of the lakes \\
\hline Glyceria lithuanica (Gorski) Gorski & & Vulnerable & & In eastern Estonia, scattered finds \\
\hline Hottonia palustris $\mathrm{L}$. & & $\begin{array}{c}\text { Near } \\
\text { Threatened }\end{array}$ & & In small watercourses and standing water bodies \\
\hline Inula britannica $\mathrm{L}$. & & $\begin{array}{c}\text { Near } \\
\text { Threatened }\end{array}$ & & On the shore of the lakes of Peipsi and Võrtsjärv \\
\hline Juncus bulbosus L. & & $\begin{array}{c}\text { Near } \\
\text { Threatened }\end{array}$ & & $\begin{array}{l}\text { Mainly in western Estonia; in shallow water and on } \\
\text { wet shore }\end{array}$ \\
\hline Lemna gibba $\mathrm{L}$. & & Vulnerable & & No need for protection, nutrient-demanding \\
\hline Limosella aquatica $\mathrm{L}$. & & Vulnerable & & Rarely, on muddy sand, at fluctuating water level \\
\hline $\begin{array}{l}\text { Pedicularis palustris ssp. palustris } \\
\text { Hupel }\end{array}$ & & $\begin{array}{c}\text { Near } \\
\text { Threatened }\end{array}$ & & $\begin{array}{l}\text { Supposedly in mires with neutral reaction of soil; } \\
\text { suffers at overgrowing? }\end{array}$ \\
\hline Peplis portula $\mathrm{L}$. & & Vulnerable & & Distribution data insufficient \\
\hline Petasites spurius (Retz.) Rchb. & & $\begin{array}{c}\text { Near } \\
\text { Threatened }\end{array}$ & & $\begin{array}{l}\text { In the dunes of the seacoast in southwest Estonia } \\
\text { and at L. Peipsi }\end{array}$ \\
\hline Pinguicula vulgaris $\mathrm{L}$. & & Vulnerable & & In alkaline fens, suffers at overgrowing \\
\hline Potamogeton acutifolius Link & & Endangered & & $\begin{array}{l}\text { Found in } 2002 \text { in L. Peipsi, distribution data } \\
\text { insufficient }\end{array}$ \\
\hline Potamogeton alpinus Balb. & & $\begin{array}{c}\text { Near } \\
\text { Threatened }\end{array}$ & & $\begin{array}{l}\text { In small lakes with sandy littoral; in undisturbed } \\
\text { rivers }\end{array}$ \\
\hline Potamogeton berchtoldii Fieber & & $\begin{array}{c}\text { Near } \\
\text { Threatened }\end{array}$ & & $\begin{array}{l}\text { Different growth forms; distribution data probably } \\
\text { mixed with P. pusillus }\end{array}$ \\
\hline Potamogeton rutilus Wolfg. & & Endangered & & Mainly in coastal lakes and in southeast Estonia \\
\hline Primula farinosa $\mathrm{L}$. & & $\begin{array}{c}\text { Near } \\
\text { Threatened }\end{array}$ & & $\begin{array}{l}\text { In alkaline fens and wet meadows; suffers at } \\
\text { overgrowing }\end{array}$ \\
\hline $\begin{array}{l}\text { Ranunculus peltatus Schrank ssp. } \\
\text { peltatus }\end{array}$ & & $\begin{array}{c}\text { Near } \\
\text { Threatened }\end{array}$ & & In coastal water bodies \\
\hline Rorippa amphibia & & $\begin{array}{c}\text { Near } \\
\text { Threatened }\end{array}$ & & $\begin{array}{l}\text { Common at water edge of lakes of Peipsi and } \\
\text { Võrtsjärv }\end{array}$ \\
\hline $\begin{array}{l}\text { Sparganium glomeratum Laest. ex } \\
\text { Beurl. }\end{array}$ & & Endangered & & Distribution data insufficient \\
\hline Stuckenia $\times$ fennica (Hagstr.) Holub & & $\begin{array}{c}\text { Near } \\
\text { Threatened }\end{array}$ & & In fast-flowing rivers of eastern Estonia \\
\hline Utricularia australis R.Br. & & Vulnerable & & $\begin{array}{l}\text { Often only vegetative plants - frequency } \\
\text { underestimated? }\end{array}$ \\
\hline Veronica catenata Pennell & & $\begin{array}{c}\text { Near } \\
\text { Threatened }\end{array}$ & & Distribution data insufficient \\
\hline
\end{tabular}

VI. The formerly open shores of the largest lakes of Peipsi (Lake Pskovsko-Chudskoe) and Võrtsjärv have been largely overgrown during the last decades; the increasing trophy level of these lakes seems to be the main reason for it. Most of the protected species occur in Lake Peipsi, namely in areas where the shallow slope is free of a wide reed belt but is not covered with concrete and stones used in harbours. Recently, this situation has been characteristic of dredged boat canals or/and smaller swimming places. In such sandy areas, Alisma gramineum Lej., Cyperus fuscus L., Potamogeton trichoides Cham. \& Schltdl., P. rutilus and P. filiformis (occurs also in L. Võrtsjärv) are growing. In the shallow sandy southern part, Elatine hydropiper L. and Scirpus radicans Schkuhr. are more frequent, and the occurrence of Bidens radiata Thuill. increases on the decomposing litter of the denuded zone in lowwater years. Among other rare species, there occur Ceratophyllum submersum L., Potamogeton acutifolius Link, Limosella aquatica L. and Ra- 
nunculus reptans L. (occurs also in L. Võrtsjärv and in some small lakes). Obviously, Subularia aquatica L. and Isoëtes echinospora Durieu have become extinct in recent decades.

QUESTIONS. An unsolved question is the status of hybrids in conservancy. In 2000-2012, the author studied all 67 lakes of Estonia where Sparganium angustifolium or/and S. gramineum, or vegetative plants of a narrow-leaved Sparganium were found earlier. The most frequent were the populations where participated Sparganium emersum Rehmann - in about half of the lakes. According to morphological characteristics, there was found only one pure population of $S$. gramineum and several very small pure populations of $S$. angustifolium (typically in lakes with Isoëtes). Most intriguing was the co-existence of only two protected species besides specimens displaying intermediate features. In some cases morphological determinations of species and their hybrids were not in accordance with the results of genetic analyses, revealing also, that involved was a species which did not occur at the time of sampling (pers. comm. L. Triest). In populations where a common species (e.g. Sparganium emersum) is more successful and gradually suppresses the rare species, very probably introgression takes place. But mixed populations of two rare species are not well-understandable by this explanation. They suggest freedom of recombination, depending mainly on the presence of the parental species. The restricted world distribution of S. gramineum (scattered occurrence in Eurasia) and only one pure population in Estonia suggest that also mixed populations may be valuable for conservation. Considering the fastness of species extinction Allendorf et al. (2001) propose to protect also complete admixtures containing the genes of disappearing species to avoid a complete loss of these species. Very probably, it is our future - in the time of more and more powerful genetics and disturbed ecosystems.

\section{Acknowledgements}

I am deeply indebted to Professor Ludwig Triest for the conduction of genetic analyses at the Vrije Universiteit in Brussel, and to the excellent specialist of the Estonian flora, Toomas Kukk, for checking the species list and for giving good advice.

This work was supported by the materials of Herbarium of the University of Life Sciences (TAA).

\section{References}

Allendorf F.W., Leary R.F., Spruell P., Wenburg J.K. 2001. The problems with hybrids: setting conservation guidelines. Trends in Ecology \& Evolution 16 (11): 613-622.

Gałka M., Tobolski K., Kołaczek P. 2012. The Holocene decline in slender naiad (Najas flexilis (Willd.) Rostk. \& W.L.E. Schmidt) in NE Poland in the light of new palaeobotanical data. Acta Palaeobotanika 52 (1): 127-138.

Kukk T. 1999. Eesti taimestik. Tartu-Tallinn: Teaduste Akadeemia Kirjastus. 464 p. [In Estonian].

Mäemets A. 1988. Haruldaste ja ohustatud veetaimede olukord Eesti järvedes. In: L. Laasimer (ed.): Taimeriigi kaitsest Eesti NSV-s. Tallinn: «Valgus». P. 65-77. [In Estonian]

Paal J. 2007. Loodusdirektiivi elupaigatüüpide käsiraamat. Tallinn: Auratrükk. 308 p. [In Estonian].

Paal J., Leibak E. 2013. Eesti soode seisund ja kaitstus. Tartu: AS Regio. 158 p. [In Estonian].

Trei T. 2001. Jõgede suurtaimestik. In: A. Järvekülg (ed.): Eesti jõed. Tartu: Tartu Ülikooli Kirjastus. 750 p. [In Estonian].

\title{
КОММЕНТИРОВАННЫЙ СПИСОК РЕДКИХ И ОХРАНЯЕМЫХ СОСУДИСТЫХ РАСТЕНИЙ ВНУТРЕННИХ ВОДОЕМОВ ЭСТОНИИ
}

\author{
Х. Мяэметс \\ Центр лимнологии Эстонского университета естественных наук, Эстония \\ e-mail:helle.maemets@emu.ee
}

\begin{abstract}
Данная статья представляет собой обзор редких и охраняемых гидрофитов, гелофитов и гигрофитов внутренних водоемов Эстонии, включающий 60 видов. В списке показаны их положение согласно категориям I-III государственной охраны (последняя версия 2014 г.) и Красной книги Эстонии (последняя версия в 2008 г.); показаны виды, представленные в работе Natura 2000. Наиболее типичные местообитания для этих редких видов: І. семидистрофные и олиготрофные (мягководные) озера; II. мезотрофные озера с Najas (Caulinia) flexilis и Potamogeton rutilus; III. топи и влажные луга па щелочном грунте; IV. солоноватоводные или пресноводные прибрежные лагуны; V. ненарушенные участки рек; VI. открытые мелководные литорали самых крупных озер Пейпси (Псковско-Чудское) и Выртсъярв. Кратко затрагиваются основные угрозы для этих местообитаний, а также проблема сохранения гибридов на основании примера видов рода Sparganium.
\end{abstract}

Ключевые слова: гибриды, категории охраны, Красная книга, основные местообитания, угроза исчезновения. 